Postprint: Steskens PWMH, Janssen H, Rode C, 2009. Influence of the convective surface transfer coefficients on the Heat, Air, and Moisture (HAM) building performance, Indoor and Built Environment, 18: 245256.

\title{
Influence of the convective surface transfer coefficients on the Heat, Air, and Moisture (HAM) building performance
}

\author{
Paul W.M.H. Steskens, Hans Janssen, Carsten Rode \\ Department of Civil Engineering, Technical University of Denmark
}

\begin{abstract}
Current models to predict heat, air and moisture (HAM) conditions in buildings assume constant boundary conditions for the temperature and relative humidity of the neighbouring air and for the surface heat and moisture transfer coefficients. These assumptions may introduce errors in the predicted HAM conditions. The paper focuses on the influence of the interior surface heat and moisture transfer coefficients, and investigates its effect on the hygrothermal performance. The parameter study showed that the magnitude of the convective surface transfer coefficients have a relatively large influence on the predicted hygrothermal conditions at the surface of a building component and on the heat and vapour exchange with the indoor environment.
\end{abstract}

\section{Keywords}

HAM component modelling, boundary conditions.

\section{Corresponding author:}

Paul W.M.H. Steskens,

Department of Civil Engineering, Technical University of Denmark, Brovej - Building 118, DK-2800 Kgs. Lyngby, Denmark

Tel: +4545251927; fax: +45 45883282

E-mail:pas@byg.dtu.dk

\section{Introduction}

Within building physics, it is generally accepted that moisture and temperature levels - and their variations in time and space - play a crucial role in both the degradation processes of building components and in the (perceived) quality of the interior environment in a building zone. Previous research has shown that the surface moisture and temperature levels are critical factors in the development of microbiological growth on building surfaces [1]. Similarly has it been shown that the interior moisture and temperature levels are essential factors in the occupants' comfort and perception of interior air quality $[2,3]$.

During the past few decades, there has been quite some development and increased professional use of tools to simulate the processes that are involved in analysis of whole building Heat, Air, and Moisture conditions in buildings. Recently, a general overview of the main features of current building simulation tools, focusing on moisture modelling and on the interactions between heat, air and moisture transfer mechanisms in buildings, has been reported by Woloszyn and Rode [4]. These authors state that the correct treatment of the interfacial flows at the boundaries between volumes of different type (interface between air and material) is a cardinal point in successful modelling. The heat, air and moisture conditions in a building component are dependent of the boundary conditions, i.e. the indoor and outdoor climate conditions. Previous experimental investigations showed that the indoor climatic conditions as well as the convective surface heat and moisture transfer coefficients near a building component may vary due to user behaviour, for 
Postprint: Steskens PWMH, Janssen H, Rode C, 2009. Influence of the convective surface transfer coefficients on the Heat, Air, and Moisture (HAM) building performance, Indoor and Built Environment, 18: 245256.

example due to heat and moisture production and ventilation strategies [5] or because of imperfect mixing and microclimatic effects [6].

Most of the tools that have been reported by Woloszyn and Rode [4] assume homogeneous indoor (and outdoor) boundary conditions, both for the temperature and relative humidity of the neighbouring air as well as for the surface heat and moisture transfer coefficients. However, since the indoor environmental conditions near a building component are variable in time and space, these HAM simulation models may thus not be able to accurately predict the HAM conditions on or in building components resulting from commonly constant boundary conditions.

This paper focuses on the magnitude of the interior surface heat and moisture transfer coefficients, and investigates how the magnitude of these coefficients may affect the hygrothermal performance of building components and building zones. For the building components, the analysis particularly emphasizes the surface relative humidity and temperature and the formation of surface moulds. For the building zones, the analysis studies the interior temperature and relative humidity and the heat and moisture buffering in the building zone.

A literature study was undertaken to obtain an overview of previous research on the modelling of the local indoor environmental conditions and the hygrothermal conditions in a building component.

As mentioned above, current simulation models to predict heat, air and moisture conditions in buildings assume homogeneous and constant surface transfer coefficients for convective heat and moisture transfer. However, researchers have shown that the convective surface transfer coefficients vary due to their strong dependency on the local air velocity [5, 6]. Moreover, Beausoleil-Morrison [7] reported that numerous researchers have examined the sensitivity of simulation predictions to the modelling of internal convection. They have demonstrated that predictions of building energy demand and consumption can be strongly influenced by the choice of the convective surface heat transfer coefficient. Holm and Künzel [8] investigated the influence of the indoor and outdoor climatic conditions on the uncertainty of the simulated hygrothermal conditions in an autoclaved aerated concrete roof. Janssen et al. [9] similarly indicated that the hygrothermal conditions in building components may be sensitive to the model applied for the external surface heat and moisture transfer coefficient. All authors recommended improvement of the models and relationships for the convective surface transfer coefficients in order to obtain a more accurate prediction of the hygrothermal conditions in a building.

Recently, an overview of the research that focused on the modelling of the convective surface heat and moisture transfer coefficients has been documented within the framework of Subtask 3 ("Boundary conditions") of the International Energy Agency project, ECBCS, Annex 41 ("Whole building heat, air and moisture response"). De Paepe [10] showed that convective surface transfer coefficients are usually obtained from fundamental theory, from experimental work, or by using numerical simulations. With respect to the theoretical approach, the heat and moisture transfer near the building component's surface is described by the boundary layer theory. Based on fundamental heat transfer theory, often the flat plate analogy is used to describe the local Reynolds $(\mathrm{Re})$ and Nusselt $(\mathrm{Nu})$ numbers along the height of the wall of a building. Regarding the determination of the surface moisture transfer coefficient the Lewis analogy is used to obtain a prediction of the surface moisture transfer coefficient based on the surface heat transfer coefficient. Both experimental research [11] and numerical investigations using computational fluid dynamics [12] have shown that the Lewis analogy for heat and moisture transfer gives a reasonable estimate of the average vapour transfer coefficient. However, Steeman et al. [12] showed that the analogy may lead to relatively large errors for local coefficients.

Experimental work has been carried out to improve the relationship between the surface transfer coefficients and the local environmental conditions: Wind-tunnel experiments [13] and 
Postprint: Steskens PWMH, Janssen H, Rode C, 2009. Influence of the convective surface transfer coefficients on the Heat, Air, and Moisture (HAM) building performance, Indoor and Built Environment, 18: 245256.

measurements in full-scale test facilities $[5,6]$ have been carried out. Researchers focused either on internal or external building surfaces.

As an alternative to laboratory investigations, researchers used numerical simulation to get a more accurate prediction of the convective surface transfer coefficients near the building component and its influence on the hygrothermal response of the building. Computational fluid dynamics has been used to model the local indoor environmental conditions and convective surface transfer coefficients [14-16].

\section{Analysis and Methods}

A parameter study was used to investigate how the magnitude of the surface transfer coefficients resulting from the air velocity near the surface of a building component - influences the hygrothermal conditions in the building component and the indoor environment. Three building components were selected as calculation objects for the analysis. Different values for the surface heat and moisture transfer coefficients were applied. Next, the hygrothermal response of the building was simulated and the simulation results are presented and discussed.

\section{Simulation strategy}

A parameter study was used to investigate how the magnitude surface transfer coefficients - resulting from the air velocity near the surface of a building component - influences the hygrothermal conditions on the building component and in the indoor environment. The simulation strategy which was applied is as follows:

The hygrothermal performance of a building zone and building components has been investigated using a coupled whole-building HAM simulation. First of all, the geometry of a building (Figure 1) which is defined along the lines of Common Exercise 1 of the IEA-ECBS Annex 41 [17], was selected for analysis. The properties of the building are presented in Table 1. The geometry of the building is coupled to the calculation objects which are presented in the following sub-section.

Second, the geometry of the building was defined in CHAMPS-Multizone [18], a multizone/network model for inter-zonal air and pollutant transport. The geometry of the calculation objects is defined in CHAMPS-BES [19], which is an envelope model for the coupled simulation of heat, air, moisture and pollutant transport in a building component. Both models are coupled in order to solve the governing equations in the different domains, i.e. in the zone and in the component, simultaneously.

Third, external boundary conditions were applied using the Test Reference Year (TRY) for Danish (Copenhagen) outdoor climatic conditions.

Fourth, the indoor environmental conditions were applied. According to the requirements of Common Exercise 1 [17] the temperature in the building is controlled to be between $20^{-} 27^{\circ} \mathrm{C}$ during the entire year. However, within the CHAMPS software environment it is not possible to control the indoor air temperature directly. To obtain comfortable indoor environmental conditions, a separate prediction of the required heating and cooling load is needed. An estimate of the required heating/cooling power can be obtained using a whole building simulation in HAMBASE [20]. The resulting heating/cooling power is supplied to the building configured in CHAMPS-Multizone. In this way, the indoor air temperature is found to be between $20^{-} 27^{\circ} \mathrm{C}$ during the entire year. Internal heat gains and moisture sources are applied according to the figures, presented in Table 1.

Fifth, different values for the surface heat and moisture transfer coefficients were applied. Lower and higher limits for the surface transfer coefficients were applied as well as a combination of a standard surface heat transfer coefficient with a lower and a higher limit for the moisture transfer coefficient. 
Postprint: Steskens PWMH, Janssen H, Rode C, 2009. Influence of the convective surface transfer coefficients on the Heat, Air, and Moisture (HAM) building performance, Indoor and Built Environment, 18: 245256.

Then, an initial temperature and relative humidity of $20{ }^{\circ} \mathrm{C}$ and $50 \% \mathrm{RH}$ respectively were applied throughout the entire building. The hygrothermal performance of the building was simulated for one year. The investigations showed that a transition period may be neglected using these initial conditions of $20{ }^{\circ} \mathrm{C}$ and $50 \% \mathrm{RH}$, which are average conditions, representative for the entire year.

\section{Calculation objects}

This section presents the building components that were analysed to investigate the influence of the surface transfer coefficients on the hygrothermal response of the building components and the building zone. It was our objective to compare the influence of the convective heat and mass transfer coefficients near the component using two wall elements and a concrete floor penetrating the external wall of a building. Figures 2 and 3 present the geometry of the calculation objects. The composition of the wall elements is presented in Table 2.

Besides the wall elements, a floor penetrating the external wall of a building was analysed. Two rooms (on top of each other) were connected by a concrete floor. Both rooms were connected to the outdoor climate by the lightweight concrete wall, consisting of a plywood cladding, a wind barrier, mineral wool insulation and a lightweight concrete layer. The construction is presented in Figure 3. The reader should notice that the original geometry of the building (Figure 1) has been extended. For this analysis, the building could be considered as two original buildings on top of each other (Figure 3). Moreover, a one-dimensional model in CHAMPS-BES [19] has been used to simulate the HAM transport in the wall elements (Figure 2), while the building corner (Figure 3) has been modelled two-dimensionally.

It was our objective to investigate the influence of the surface heat transfer coefficients on the hygrothermal performance in the component when considering a thermal bridge, such as a balcony. Due to inertia effects, the air velocity near the corners was relatively low compared to the average air velocity in the room. Lower air velocities result in relatively low convective surface heat and mass transfer coefficients near the corner compared to the surface transfer coefficients in the centre of the components.

\section{Parameter analysis}

Several indoor environmental conditions, presented in Table 3, were investigated. Based on the observations obtained from the literature study [21,22], typical values for the convective heat and moisture transfer coefficients were applied for the different indoor environmental conditions. The objective of the investigations ( 1 and 2 ) was to determine minimum and maximum hygrothermal conditions, which were likely to occur in the building component and the building zone. The objective of studying the conditions using a standard value for the convective surface heat transfer coefficient (conditions 3 and 4) was to compare the influences of the convective surface heat transfer coefficient and the surface moisture transfer coefficient separately. The hygrothermal response of the building was simulated using the values presented for the convective surface transfer coefficients, applied to the presented building components (Figures 2 and 3 ). For the convective surface transfer coefficients of other components, such as the floor and ceiling, values based on Beausoleil-Morrison [7] were applied.

\section{Results}

\section{Hygrothermal conditions on building components}

The predicted surface conditions on the walls and interior conditions in the room were analyzed. We give here the predicted hygrothermal conditions on the internal surface of the components (see Figures 2 and 3). First of all, the surface temperature and relative humidity on the wall elements (Figure 2) during 2 days are presented. Second, weekly averaged surface conditions on the presented components were analysed by presentation in an isopleth. Since the results 
Postprint: Steskens PWMH, Janssen H, Rode C, 2009. Influence of the convective surface transfer coefficients on the Heat, Air, and Moisture (HAM) building performance, Indoor and Built Environment, 18: 245256.

obtained from the simulation of the timber frame wall are comparable to the results for the lightweight concrete wall, only the results obtained from the lightweight concrete wall simulations are presented. Third, the surface temperature and relative humidity in the corner of the thermal bridge (Figure 3) are shown.

Wall elements: Figure 4 shows the surface temperature, the surface relative humidity and the partial vapour pressure at the internal surface of the lightweight concrete wall during 2 days (May 27-28). The selected period is representative for the entire year. Figure 4 shows that a notable difference is present between the lower limit (1) and the higher limit (2). Comparing the surface conditions for the average surface heat transfer coefficient and lower and higher limits for the surface moisture transfer coefficient (conditions (3) and (4)), Figure 4 presents a relatively small deviation. Moreover, analysis of the partial vapour pressure shows, that a relatively small difference between the investigated limits is observed. From this observation, it may be concluded that the influence of the convective surface heat transfer coefficient on the hygrothermal performance is relatively large compared to the influence of the convective surface moisture transfer coefficient.

Figure 5 shows the surface conditions on the lightweight concrete wall predicted over the entire year from an analysis using an isopleth. The isopleth was based on daily averaged values for the surface temperature and relative humidity. Figure 5 shows that the difference between the observed conditions when applying lower (1) and higher limits (2) for the surface transfer coefficients is limited. When applying lower limits (1) for the surface transfer coefficients compared to the application of higher limits (2), the histograms show a comparable distribution. The number of days during which the surface conditions exceed $70 \% \mathrm{RH}$ is relatively similar for both cases.

Building corner: Figure 6 presents the temperature, the relative humidity and the partial vapour pressure in the corner of the building component during 2 days (May 27-28.). The figure shows that a relatively large difference is present between the lower limit (1) and the higher limit (2). Moreover, considering the hygrothermal conditions between the standard surface heat transfer coefficient and lower and higher limits for the surface moisture transfer coefficient (conditions (3) and (4)), the difference is significant.

Comparing the simulation results of the components and the thermal bridge for the standard surface heat transfer coefficient and lower and higher limits for the surface moisture transfer coefficient (conditions (3) and (4)), the surface moisture transfer coefficient is shown to be more important when considering the thermal bridge. At the same time, the reader should realize that while the surface moisture coefficient has a larger influence here, the influence of the surface heat transfer coefficient is still dominant. Analysis of the relative humidity (Figure 6) shows that values of the predicted relative humidity, when assuming an average heat transfer coefficient (conditions (3) and (4)), lie closer to each other compared to the conditions with lower limits (1) and higher limits (2).

Figure 7 presents the temperature and relative humidity in the corner of the building component. The predicted conditions when applying lower limits (1) and higher limits (2) for the surface transfer coefficients have been compared. The daily averaged temperatures and relative humidities are presented in the isopleth. Comparing the simulation results for the wall elements (Figure 5) and the thermal bridge (Figure 7), the results show that the difference in the predicted hygrothermal conditions is relatively large for the thermal bridge. 
Postprint: Steskens PWMH, Janssen H, Rode C, 2009. Influence of the convective surface transfer coefficients on the Heat, Air, and Moisture (HAM) building performance, Indoor and Built Environment, 18: 245256.

\section{Hygrothermal conditions in building zones}

In this section, the influence of the surface heat and mass transfer coefficients on the hygrothermal conditions in the building zone is presented. Figure 8 shows the average indoor air temperature and relative humidity in the building zone for timber frame wall (TF) and the lightweight concrete wall (LC) with lower (1) and higher limits (2) for the surface transfer coefficients during 2 days (May 27-28). The simulation results show that the influence of both the surface heat transfer coefficient and the surface moisture transfer coefficient on the indoor environmental conditions is relatively large. Assuming standard values for the surface transfer coefficients may introduce relatively large errors in the prediction of the heat and moisture fluxes to and from the indoor environment and the prediction of the indoor environmental conditions.

In Figure 9, the amplitude of the indoor air temperature for both walls using lower (1) and higher limits (2) is presented. The amplitude is defined by Equation (1).

$\Delta T=\left|T_{\max }-T_{a v g}\right|$

where $\mathrm{T}_{\text {avg }}\left[{ }^{\circ} \mathrm{C}\right]$ is the daily averaged indoor air temperature, and $\mathrm{T}_{\max }\left[{ }^{\circ} \mathrm{C}\right]$ is the maximum indoor air temperature of that day.

Comparing the amplitudes of the indoor air temperature, Figure 9 shows that the lightweight concrete wall's ability to buffer heat is relatively large compared to the timber frame wall, resulting in relatively small amplitudes. Moreover, the figure shows that the surface heat transfer coefficient has a relatively large influence on the heat buffering of the component.

Similarly the amplitude of the hourly relative humidity of the indoor air, defined by Equation (2), for both walls is presented in Figure 10. Figure 10 shows that the moisture buffering capacity of both walls is comparable.

$$
\Delta R H=\left|R H_{\max }-R H_{\text {avg }}\right|
$$

Analysing the influence of the surface transfer coefficients on the indoor air temperature and relative humidity (Figure 9 and 10), the range of predicted indoor air temperature and relative humidity is relatively narrow, when applying higher limits (2). This means that peaks are reduced and instantaneous increases or decreases in indoor air temperature and relative humidity are levelled out.

\section{Discussion}

Analysis of the simulation results showed that the influence of the convective surface heat transfer coefficient on the hygrothermal conditions on the building component (Figures 4 and 6) was relatively large compared to the influence of the convective surface mass transfer coefficient. An explanation for this could be obtained by analyzing the material and surface resistances for heat and moisture transport.

Analyzing the building components (Figure 2), the thermal resistance of the building materials is approximately $4 \mathrm{~m}^{2} \mathrm{~K} \mathrm{~W}^{-1}$, while the surface heat transfer resistances lie between 0.33 $\mathrm{m}^{2} \mathrm{~K} \mathrm{~W}^{-1}$ down to $0.061 \mathrm{~m}^{2} \mathrm{~K} \mathrm{~W}^{-1}$. For heat transfer hence, the magnitude of the surface resistance is approximately $5 \%$ of the material's thermal resistance. Regarding the thermal bridge, the resistance of approximately $30 \mathrm{~cm}$ of concrete is approximately $0.2 \mathrm{~m}^{2} \mathrm{~K} \mathrm{~W}^{-1}$, resulting in a relatively larger influence of the surface transfer resistance compared to the material's thermal resistance.

Focussing on the moisture transfer, the moisture transfer resistances of the building materials are approximately $6 \times \cdot 10^{9}, 13 \times \cdot 10^{9}$, and $29 \times \cdot 10^{9} \mathrm{~m} \mathrm{~s}^{-1}$ for the timber frame wall, the lightweight concrete wall, and the thermal bridge respectively. Comparing these resistances to the surface transfer resistances varying between $0.01 \cdot 10^{9}-0.1 \cdot 10^{9} \mathrm{~m} \mathrm{~s}^{-1}$ shows that the surface moisture transfer resistance is negligible (less than 1\%) compared to the material's resistance. Thus, the 
Postprint: Steskens PWMH, Janssen H, Rode C, 2009. Influence of the convective surface transfer coefficients on the Heat, Air, and Moisture (HAM) building performance, Indoor and Built Environment, 18: 245256.

influence of the thermal surface resistance on the behaviour of component and the thermal bridge should be larger compared to the influence of the hygric surface resistance.

Under transient conditions, the penetration depth $\mathrm{d}_{\mathrm{p}}$ and the related material layer's heat and moisture capacity are best able to quantify the potential for materials to damp changes in indoor temperature and humidity respectively. The active thickness of a material for heat and moisture exchange is estimated using the penetration depth, represented by Equations (3) and (4) [23].

$$
\begin{aligned}
& d_{p, H}=\sqrt{\frac{\lambda t_{p}}{\rho c \pi}} \\
& d_{p, M}=\sqrt{\frac{\delta p_{\text {vsat }} t_{p}}{\xi \pi}}
\end{aligned}
$$

where $d_{p}$ is the penetration depth $[\mathrm{m}], \lambda$ the thermal conductivity $\left[\mathrm{W} \mathrm{m}^{-1} \mathrm{~K}^{-1}\right]$, $\rho$ the density $\left[\mathrm{kg} \mathrm{m}^{-3}\right]$, $\mathrm{c}$ the heat capacity $\left[\mathrm{J} \mathrm{kg}^{-1} \mathrm{~K}^{-1}\right], \delta$ is the vapour permeability of the material $[\mathrm{s}], \zeta$ the moisture capacity of the material $\left[\mathrm{kg} \mathrm{m}^{-3}\right]$, and $\mathrm{t}_{\mathrm{p}}$ is the period of time of the moisture production cycle $[\mathrm{s}]$. The active thickness and the moisture capacity of the materials used on the internal side of the walls and the thermal bridge are presented in Table 4.

The ratio between the influence of the surface resistance and the material resistance on the heat and moisture transport is described by the Biot number. Equations (5) and (6) present the Biot numbers for heat and moisture transfer respectively.

$$
\begin{aligned}
& B i_{H}=\frac{\alpha_{c} L_{H}}{\lambda} \\
& B i_{M}=\frac{\beta_{c} L_{M}}{\delta}
\end{aligned}
$$

where $\alpha_{c}$ is the convective surface heat transfer coefficient $\left[\mathrm{W} \mathrm{m}^{-2} \mathrm{~K}^{-1}\right], \beta_{\mathrm{c}}$ is the convective surface moisture transfer coefficient, and $\mathrm{L}_{\mathrm{H}}$ and $\mathrm{L}_{\mathrm{M}}$ are the characteristic lengths for heat and moisture transfer. Considering the porous wood fibre board, the reader should notice that the characteristic length $\left(\mathrm{L}_{\mathrm{M}}\right)$ is equal to half of the active thickness of the material $\left(\mathrm{d}_{\mathrm{p}, \mathrm{M}}\right)$, while the characteristic length for heat transfer $\left(\mathrm{L}_{\mathrm{H}}\right)$ is equal to half of the thickness of the material $(\mathrm{d})$, since the material thickness is lower than the thermal penetration depth.

Table 4 presents the corresponding Biot numbers for heat and moisture transfer for the timber frame wall, the lightweight concrete wall, and the thermal bridge. The table shows that, focusing on the heat transport, the Biot numbers $\left(\mathrm{Bi}_{\mathrm{H}}\right)$ of all materials are smaller than 0.1 and within the same order of magnitude. Since the Biot numbers for heat transfer of both materials are smaller than 0.1 , this indicates that the surface transfer resistance has a relatively large influence on the thermal behaviour of the building component.

With respect to the moisture transport $\left(\mathrm{Bi}_{\mathrm{M}}\right)$, the Biot numbers of the components are larger than 0.1 , and in this case a lumped system analysis is not applicable, indicating that changes in the surface transfer coefficient will have a relatively smaller influence on the hygric behaviour of the component, as the internal resistance to moisture transport is also significant.

In conclusion, the analysis of the material and surface resistances for heat and moisture transport confirmed the observations that the influence of the convective surface heat transfer coefficients is relatively large compared to the influence of the convective surface moisture transfer coefficient on the hygrothermal response of the building components.

The convective surface transfer coefficients were also shown to have an influence on the hygrothermal conditions in the building zone via the thermal and hygric buffering of the building components, i.e. the amplitudes of the indoor air temperature and relative humidity in the room. 
Postprint: Steskens PWMH, Janssen H, Rode C, 2009. Influence of the convective surface transfer coefficients on the Heat, Air, and Moisture (HAM) building performance, Indoor and Built Environment, 18: 245256.

Analysis of the thermal and hygric effusivity, which represent the measure of the material's ability to exchange heat and moisture with its surroundings is done using Equations (7) and (8).

$e_{H}=\sqrt{\lambda \rho c}$

$e_{M}=\sqrt{\xi \delta / p_{v s a t}}$

where $\lambda$ is the thermal conductivity $\left[\mathrm{W} \mathrm{m} \mathrm{K}^{-1}\right], \rho$ the density $\left[\mathrm{kg} \mathrm{m}^{-3}\right]$, c the heat capacity $\left[\mathrm{J} \mathrm{kg}^{-1} \mathrm{~K}^{-}\right.$ $\left.{ }^{1}\right], \delta$ is the vapour permeability of the material $[\mathrm{s}]$, and $\xi$ the moisture capacity of the material $\left[\mathrm{kg} \mathrm{m}^{-}\right.$ $\left.{ }^{3} \mathrm{~Pa}^{-1}\right]$.

Focusing on the indoor air temperature in the room, Figures 8 and 9 show that the lightweight concrete wall has a larger heat buffering capacity compared to the timber frame wall, i.e. the peaks in the indoor air temperature are reduced. Moreover, the range of indoor temperatures when applying the lightweight concrete wall is relatively narrow compared to the timber frame wall. Comparing the relative humidity in the room (Figure 8 and 10), the results show that the hygric buffering capacity of both walls is relatively similar.

However, comparison of the effusivities for both materials, Table 4 showed that the ability of the lightweight concrete to buffer both heat and moisture is relatively large compared to the ability of the timber frame wall. The reader should notice that the specific values for the surface transfer coefficient which are applied in the simulation influence the heat and moisture buffering capacity of the wall indirectly and determine the predicted indoor environmental conditions.

From this work we concluded that while the influence of the convective surface transfer coefficients on the HAM conditions on the surface of the insulated walls was limited, this influence was relatively large when considering a thermal bridge. Different surface temperature, relative humidity and vapour pressures were predicted when different airflow conditions near a component resulted in different convective surface transfer coefficients. In consequence. when performing a hygrothermal performance analysis and simulation, it is important to take the local airflow velocity near the component into account.

When focusing on the hygrothermal performance of walls, the influence of the convective surface heat transfer coefficient on the hygrothermal performance is relatively large compared to the influence of the convective surface moisture transfer coefficient. With respect to the analysed building components, the investigations showed that assuming an average value for the convective surface moisture transfer coefficient is acceptable, while assuming an average value for the convective surface heat transfer coefficient is not acceptable. The study showed that the influence on the surface relative humidity is limited. However, an influence on the exchange with the interior environment is still present.

With respect to the hygrothermal performance of the thermal bridge, the influence of both the convective surface heat and moisture transfer coefficient on the hygrothermal performance is relatively large. The analysis showed that assuming an average value for these coefficients is not acceptable.

The influence of both the surface heat transfer coefficient and the surface moisture transfer coefficient on the heat and vapour exchange between the building component and the indoor environment as well as the buffering capacity of the building component is relatively large. Assuming average values for the surface transfer coefficients may introduce relatively large errors in the prediction of these fluxes and the prediction of the indoor environmental conditions. 
Postprint: Steskens PWMH, Janssen H, Rode C, 2009. Influence of the convective surface transfer coefficients on the Heat, Air, and Moisture (HAM) building performance, Indoor and Built Environment, 18: 245256.

Building researchers and designers should be aware that the appropriate indoor environmental conditions should be applied when performing a hygrothermal component simulation and analysis. The local airflow conditions near the component have a relatively large influence on the predicted hygrothermal conditions on the surface of the component. It is recommended that, for example in a design stage, different local airflow conditions are investigated to predict the influence of these conditions on the hygrothermal performance of the specific component.

Future research should focus on the prediction of the local air velocity near interfaces and on the analysis and determination of the relationship between the local air velocity and the convective surface heat transfer coefficient. A more detailed description and prediction of the interaction between the indoor environment and the hygrothermal conditions in the building component is desirable. The quality of such an analysis would be improved by providing guidelines and relationships between the convective surface heat transfer coefficient and the local air velocity near the building component.

\section{Conclusions}

The influence of the surface heat and moisture transfer coefficients on the hygrothermal conditions on building components and in the building zone has been analysed. A literature study was undertaken to obtain an overview of the previous research on the on the modelling of the local indoor environmental conditions and the hygrothermal conditions in a building component. Lower and upper limits for the convective surface transfer coefficients $\left(\alpha_{c}\right.$ and $\left.\beta_{c}\right)$ were assigned. A parameter study was used to investigate how the magnitude of the surface transfer coefficients resulting from the air velocity near the surface of a building component - varied with the hygrothermal conditions in the building component and the indoor environment. Three building component configurations (calculation objects) were selected for analysis. Different values for the surface heat and moisture transfer coefficients were applied and the hygrothermal response of the building was simulated. The simulated conditions resulted in minimum and maximum hygrothermal conditions in the building component and in the building zone.

\section{References}

1. Sedlbauer K, Krus M: Mold growth on ETICS (EIFS) as a result of "bad workmanship"? J Thermal Envelope Building Sci 2002;26(2): 117-121.

2. Marshall PH: Addressing indoor air quality concerns: Occupational Hazards 1996;58(1): 83.

3. Arens EA, Baughman AV: Indoor humidity and human health: Part II - buildings and their systems. ASHRAE Trans 1996;102(1):212-221.

4. Woloszyn M, Rode C: Tools for performance simulation of heat, air and moisture conditions of whole buildings: Building Simulation 2008; 1(1):5-24.

5. Bednar T, Dreyer J: Determination of moisture surface transfer coefficients under transient conditions: in International Building Physics Conference II, Leuven, 2003.

6. Mortensen LH, Rode C, Peuhkuri R: Effect of airflow velocity on moisture exchange at surface of building materials: in Fazio P, Ge H, Rao J, Desmarais G (eds): Proceedings of the 3rd IBPC Conference, Montreal, London, Taylor and Francis Group.

7. Beausoleil-Morrison I: The adaptive simulation of convective heat transfer at internal building surfaces: Building Environ 2002;37(8-9): 791-806.

8. Holm A, Ku" nzel HM: Uncertainty approaches for hygrothermal building simulations - drying of an AAC flat roof in different climates: in $7^{\text {th }}$ International IBPSA Conference, Brazil, 2001.

9. Janssen H, Blocken B, Carmeliet J: Conservative modelling of the moisture and heat transfer in building components under atmospheric excitation: Int. J Heat Mass Transfer 2007;50(5-6):11281140 . 
Postprint: Steskens PWMH, Janssen H, Rode C, 2009. Influence of the convective surface transfer coefficients on the Heat, Air, and Moisture (HAM) building performance, Indoor and Built Environment, 18: 245256.

10. De Paepe M: Surface transfer coefficients: in Kumaran K, Sanders C (eds): Annex 41, Whole building Heat, Air, Moisture Response. Boundary Conditions and Whole Building HAM Analysis, 2008, pp. 65-110.

11. Schwarz B: Die Wärme- und Stoffübertragung an Außenwandoberflächen: PhD Thesis, Univ. Stuttgart, Institut für Bauphysik der Fraunhofer-Gesellschaft Aussenstelle Holzkirchen, 1972.

12. Steeman HJ, Janssens A, De Paepe M: About the use of the heat and mass analogy in building simulation: in 12th Symp Building Phys, Technical University Dresden, Dresden, 2007, p. 455.

13. Talev G, Gustavsen A, Næss E: Influence of the velocity, local position, and relative humidity of moist air on the convective mass transfer coefficient in a rectangular tunnel - Theory and experiments: J Building Phys 2008; 32(2):155-173.

14. Steeman HJ, T'Joen C, Willockx A, De Paepe M, Janssens A: CFD modeling of HAM transport in buildings: Boundary conditions: in Fazio P, Ge H, Rao J, Desmarais G (eds): Proceedings of the 3rd IBPC Conference, Montreal, London, Taylor \& Francis Group.

15. Mortensen LH, Woloszyn M, Rode C, Peuhkuri R: Investigation of microclimate by CFD modeling of moisture interactions between air and constructions: J Building Phys 2007;30(4):279-315.

16. Neale A, Derome D, Blocken B, Carmeliet J: Coupled simulation of vapor between air and a porous material: in Buildings X Conference Proceedings, Am Soc Heating, Refrig Air-Con Engineer, Inc., 2007.

17. Rode C, Woloszyn M: Common exercise 1 (whole building heat, air and moisture analysis), Intl Energy Agency, Energy Conserv Buildings Community Systems Programme, Annex 41 - Subtask 1, 2004.

18. Nicolai A, Zhang JS, Grunewald J: Coupling strategies for combined simulation using multizone and building envelope models: in Proceedings of the 10th International Building Performance Simulation Association (IBPSA) Conference, 2007, p. 1506.

19. Nicolai A, Grunewald J: CHAMPS-BES Program for Coupled Heat, Air, Moisture and Pollutant Simulations in Building Envelope Systems (User Manual), BEESL - Building Energy and Environmental Systems Laboratory, Department of Mechanical and Aerospace Engineering, Syracuse University, NY, Syracuse, NY, 2006.

20. de Wit MH: HAMBASE - Heat Air and Moisture Model for Buildings and Systems Evaluation. Eindhoven, The Netherlands, Eindhoven University Press, 2006.

21. Cengel YA: Heat Transfer: A Practical Approach. New York, McGraw-Hill, 2003.

22. Hens HSLC: Building Physics - Heat, Air and Moisture - Fundamentals and Engineering Methods with Examples and Exercises. Berlin, Ernst \& Sohn, 2007.

23. Cunningham MJ: Effective penetration depth and effective resistance in moisture transfer: Building Environ 1992; 27(3):379-386. 
Postprint: Steskens PWMH, Janssen H, Rode C, 2009. Influence of the convective surface transfer coefficients on the Heat, Air, and Moisture (HAM) building performance, Indoor and Built Environment, 18: 245256.

\section{TABLES AND ILLUSTRATIONS}

\section{Figure and Table Captions}

Figure 1: Geometry of the building [17]

Figure 2: The composition of the timber frame and lightweight concrete wall.

Figure 3: Building detail selected for analysis.

Figure 4: Surface temperature, relative humidity and vapour pressure at the internal side of the light weight concrete wall.

Figure 5: Predicted surface conditions for the lightweight concrete wall using lower (1) and higher limits (2) for the surface transfer coefficients. Isopleth representation of the daily averaged surface conditions during one year. Histogram of the observed daily averaged surface relative humidity as a function of the number of days.

Figure 6: Surface temperature and relative humidity in the corner of the building component. The different conditions, i.e. lower limits, higher limits and average values for the surface transfer coefficients corresponding.

Figure 7: Temperature and relative humidity in the corner of the thermal bridge using lower (1) and higher limits (2) for the surface transfer coefficients. Isopleth representation of the daily averaged surface conditions during one year. Histogram of the observed daily averaged surface relative humidity as a function of the number of days.

Figure 8: Average indoor air temperature and relative humidity in the room during 2 days (May 2728). The results obtained from the simulations of the timber frame wall and the lightweight concrete wall with lower (1) and higher limits (2) for the surface transfer coefficients are compared.

Figure 9: Amplitude of the indoor air temperature in the room, defined by Equation (1), obtained from the simulations of the timber frame wall and the lightweight concrete wall with lower and higher limits for the surface transfer coefficients are compared.

Figure 10: Amplitude of the indoor relative humidity (Equation (2)) in the room obtained from the simulations of the timber frame wall and the lightweight concrete wall with lower and higher limits for the surface transfer coefficients are compared.

Table 1: Building properties

Table 2: Wall elements

Table 3. Convective heat and moisture transfer coefficients, which have been applied for the different indoor environmental conditions.

Table 4: Material properties 
Postprint: Steskens PWMH, Janssen H, Rode C, 2009. Influence of the convective surface transfer coefficients on the Heat, Air, and Moisture (HAM) building performance, Indoor and Built Environment, 18: 245256.

\section{Figure 1}

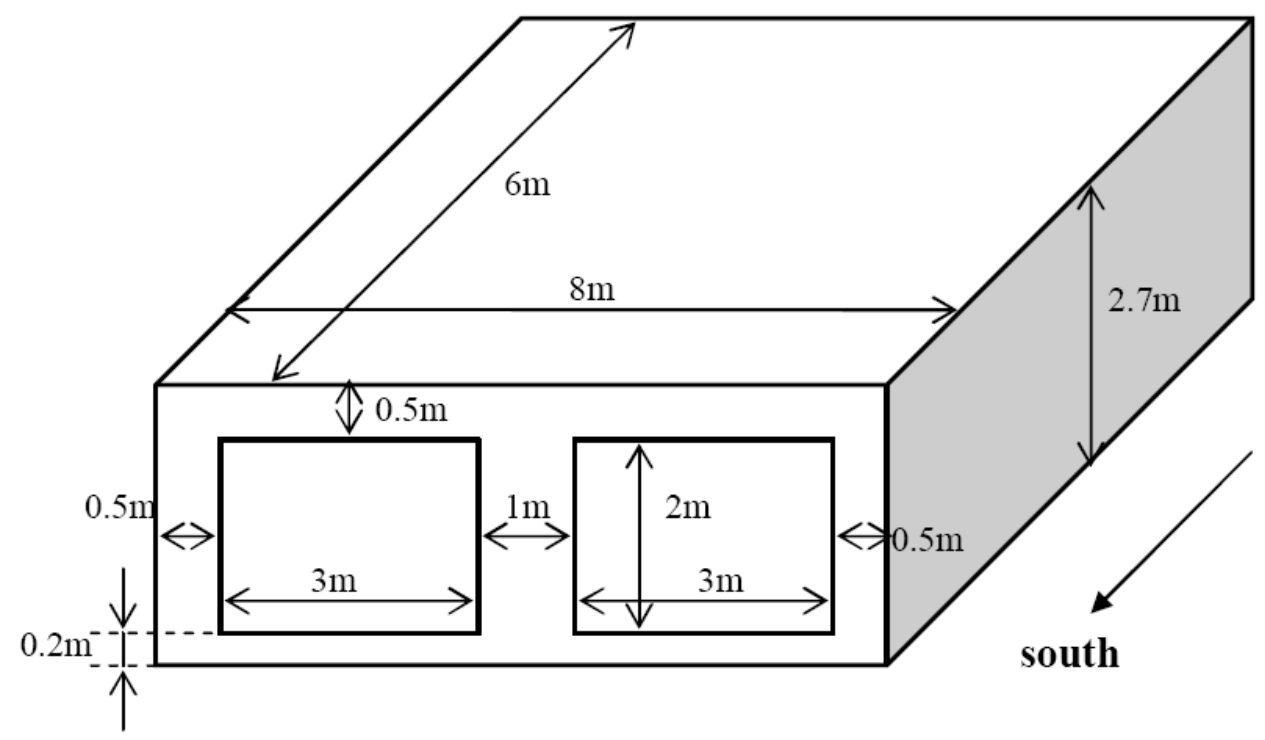

Figure 2
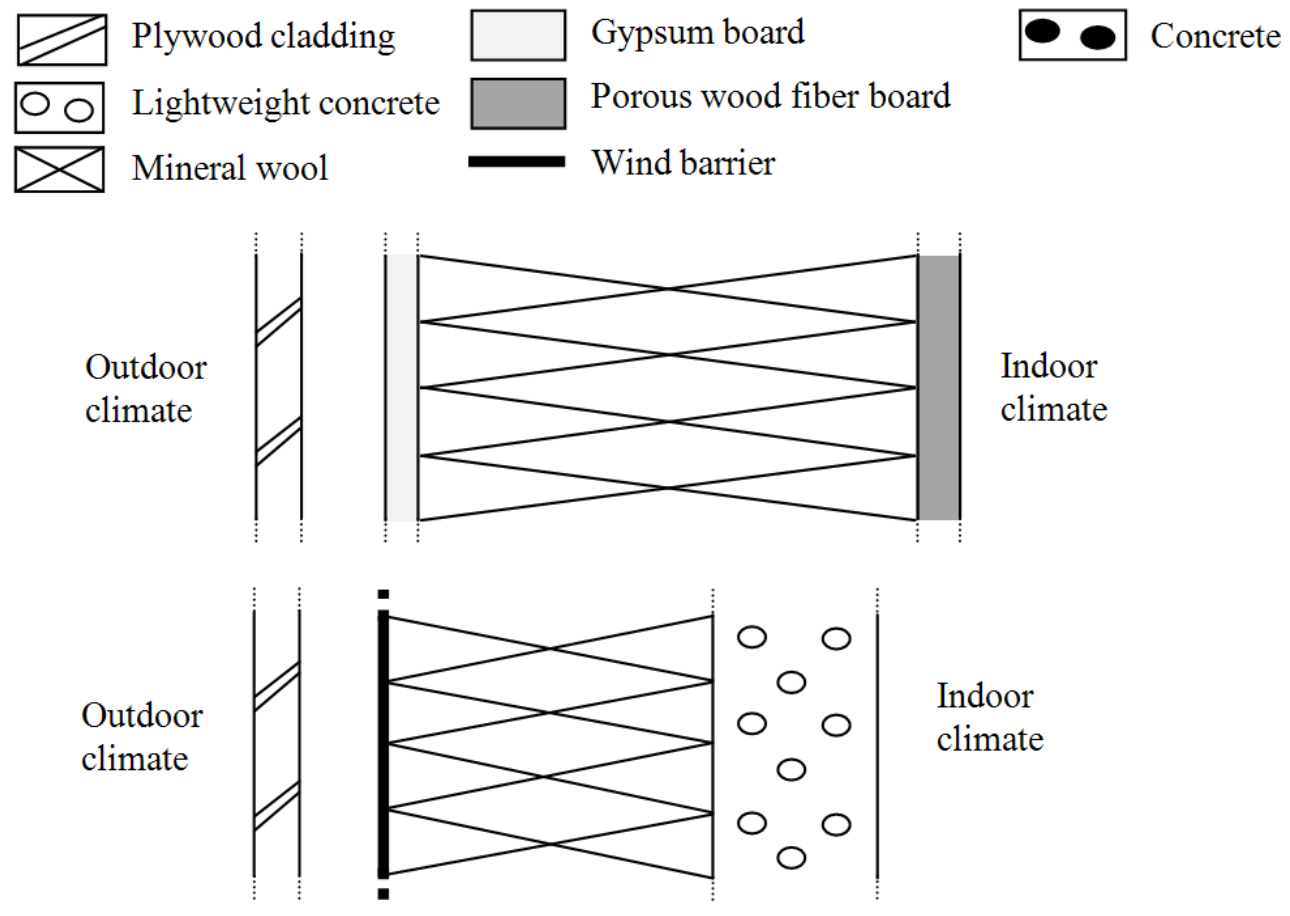
Postprint: Steskens PWMH, Janssen H, Rode C, 2009. Influence of the convective surface transfer coefficients on the Heat, Air, and Moisture (HAM) building performance, Indoor and Built Environment, 18: 245256.

Figure 3
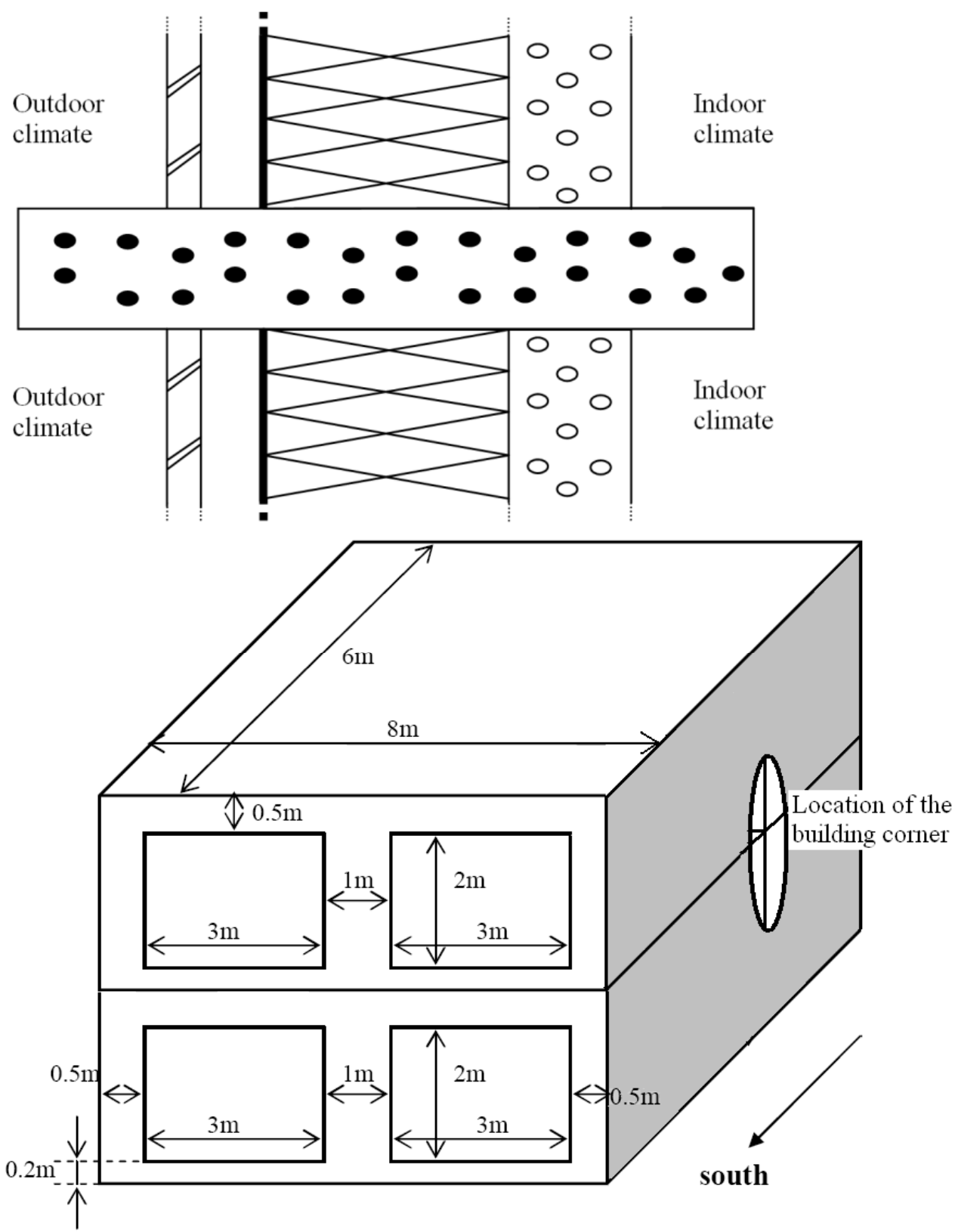
Postprint: Steskens PWMH, Janssen H, Rode C, 2009. Influence of the convective surface transfer coefficients on the Heat, Air, and Moisture (HAM) building performance, Indoor and Built Environment, 18: 245256. doi: $10.1177 / 1420326$ X09105682

\section{Figure 4}
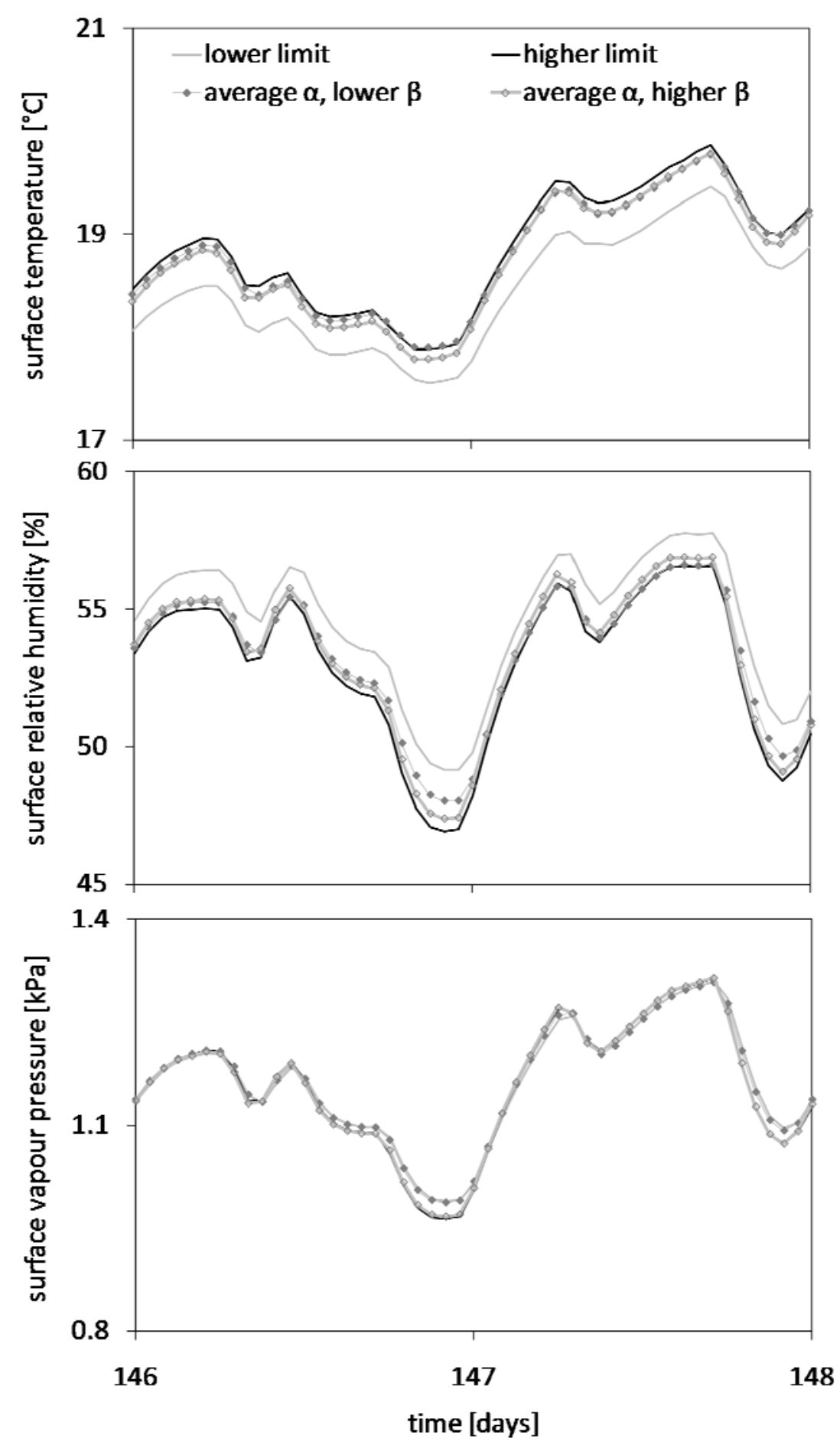
Postprint: Steskens PWMH, Janssen H, Rode C, 2009. Influence of the convective surface transfer coefficients on the Heat, Air, and Moisture (HAM) building performance, Indoor and Built Environment, 18: 245256.

\section{Figure 5}
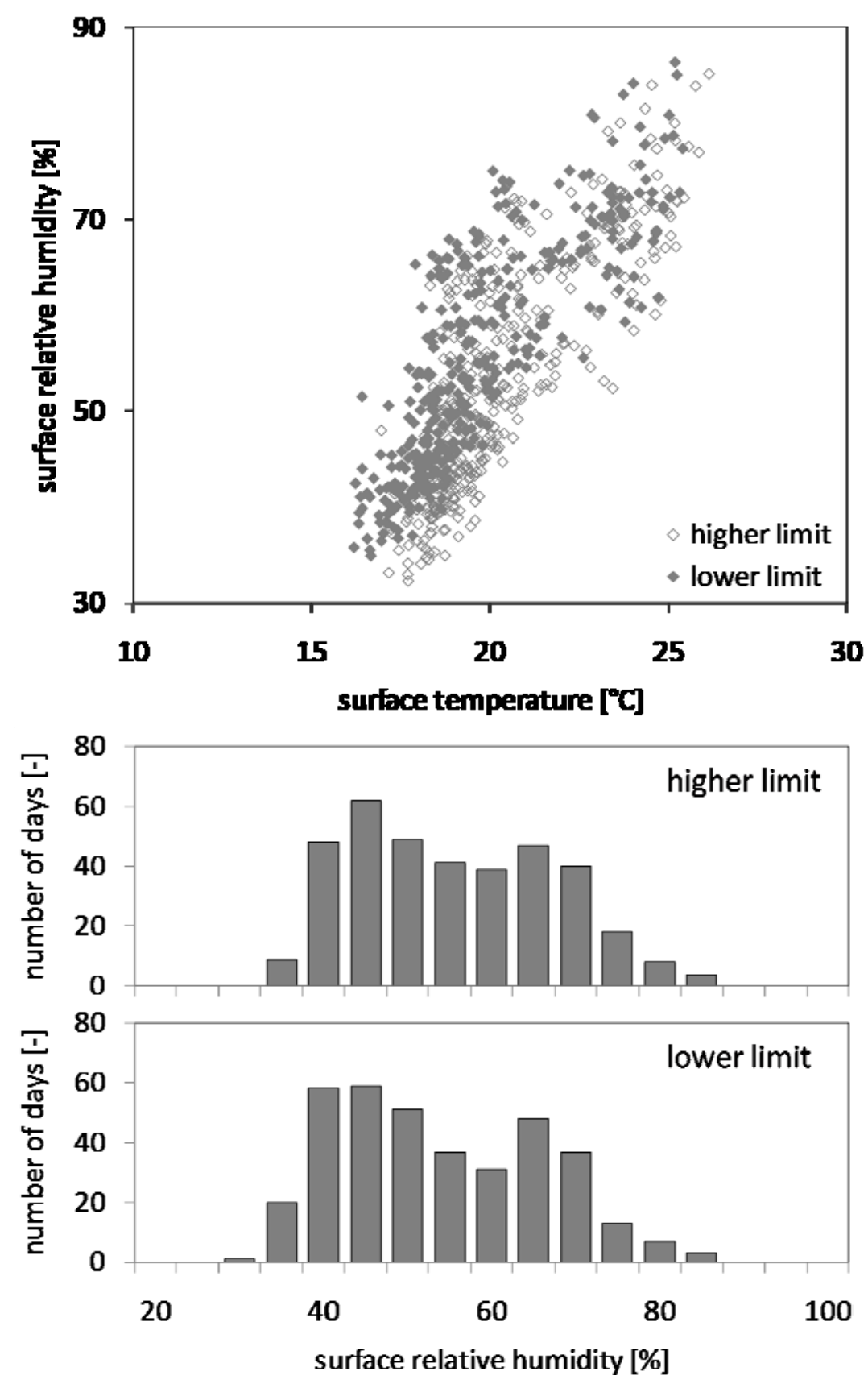
Postprint: Steskens PWMH, Janssen H, Rode C, 2009. Influence of the convective surface transfer coefficients on the Heat, Air, and Moisture (HAM) building performance, Indoor and Built Environment, 18: 245256.

\section{Figure 6}
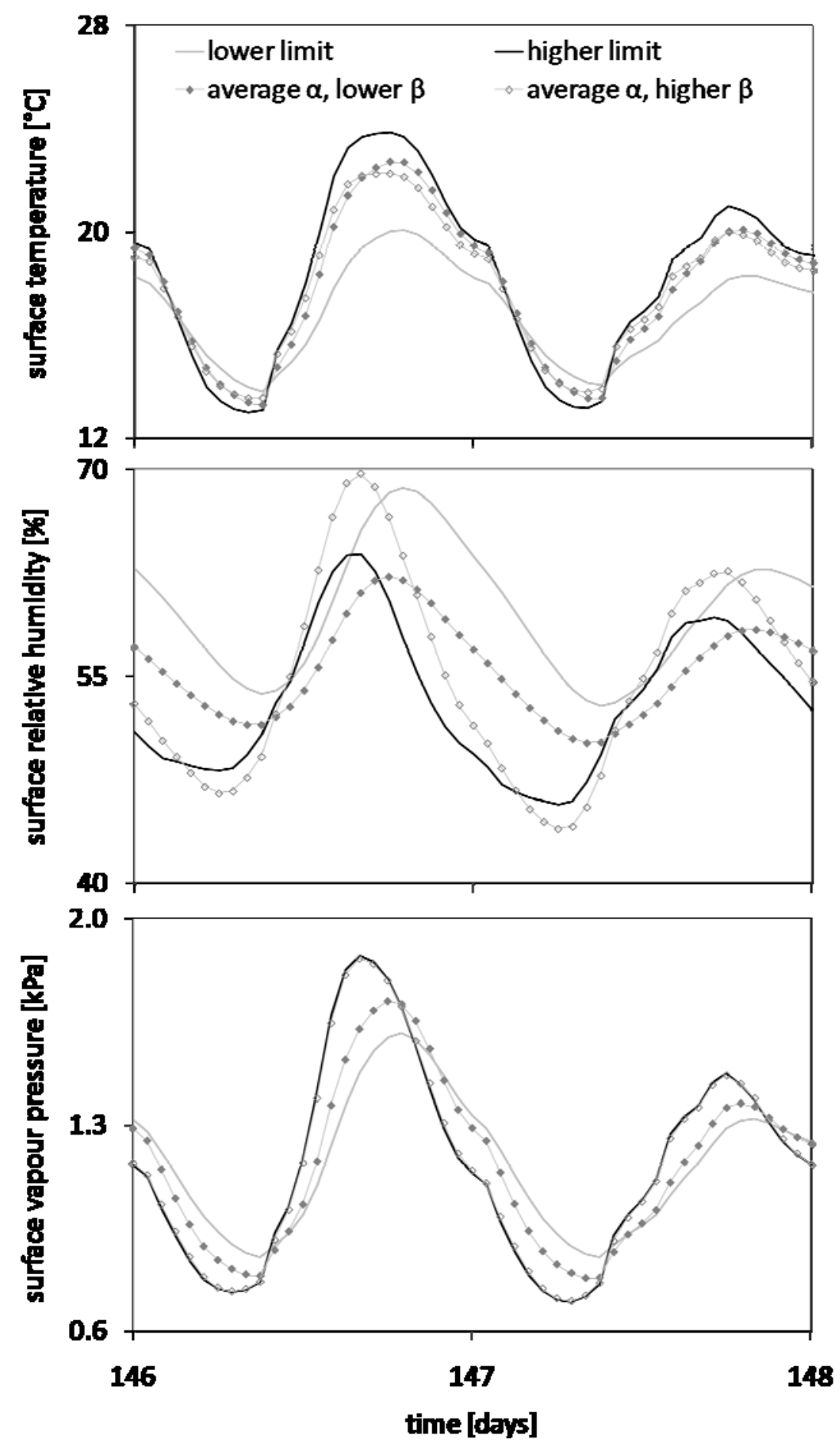
Postprint: Steskens PWMH, Janssen H, Rode C, 2009. Influence of the convective surface transfer coefficients on the Heat, Air, and Moisture (HAM) building performance, Indoor and Built Environment, 18: 245256. doi: 10.1177/1420326X09105682

\section{Figure 7}
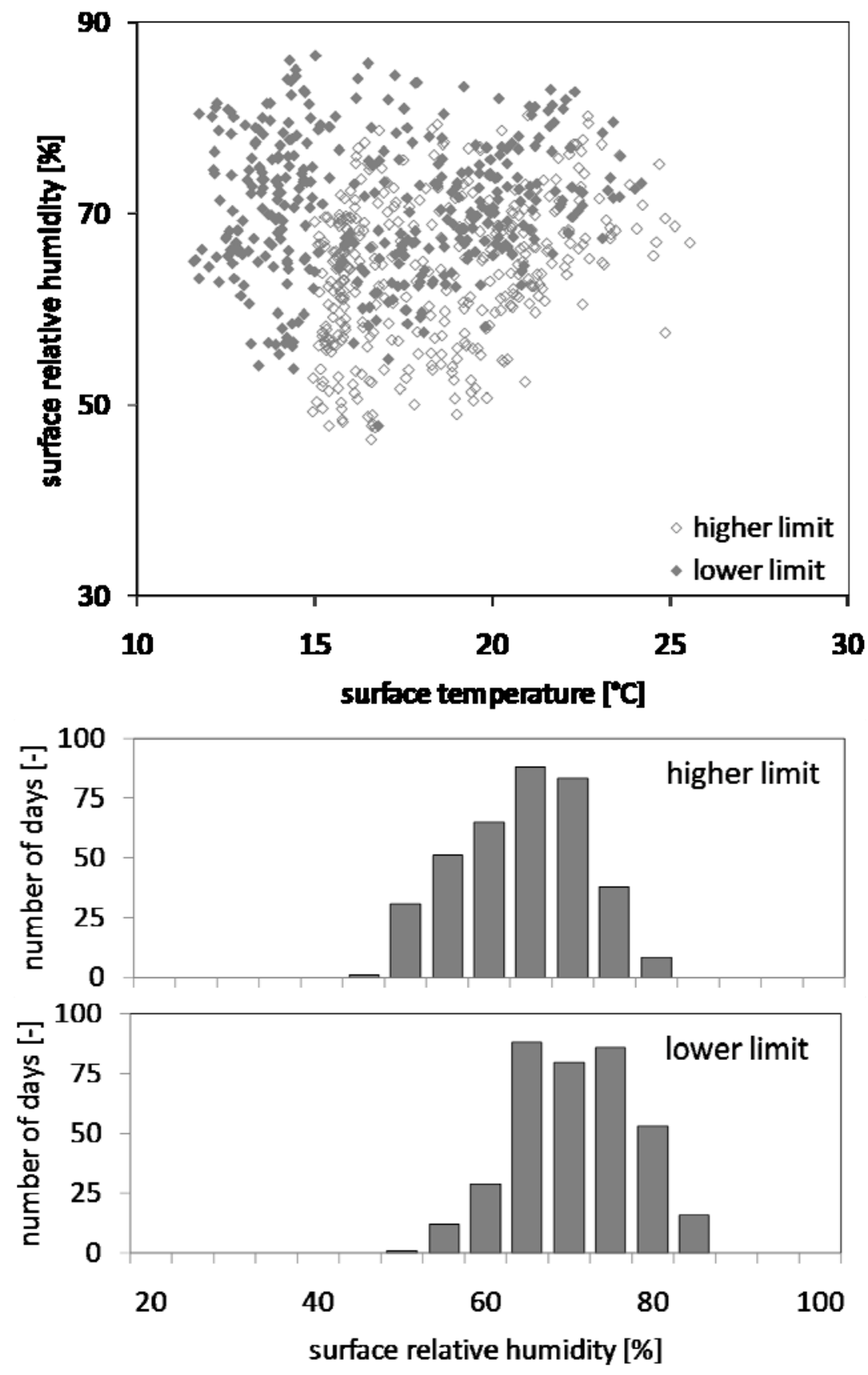
Postprint: Steskens PWMH, Janssen H, Rode C, 2009. Influence of the convective surface transfer coefficients on the Heat, Air, and Moisture (HAM) building performance, Indoor and Built Environment, 18: 245256.

\section{Figure 8}

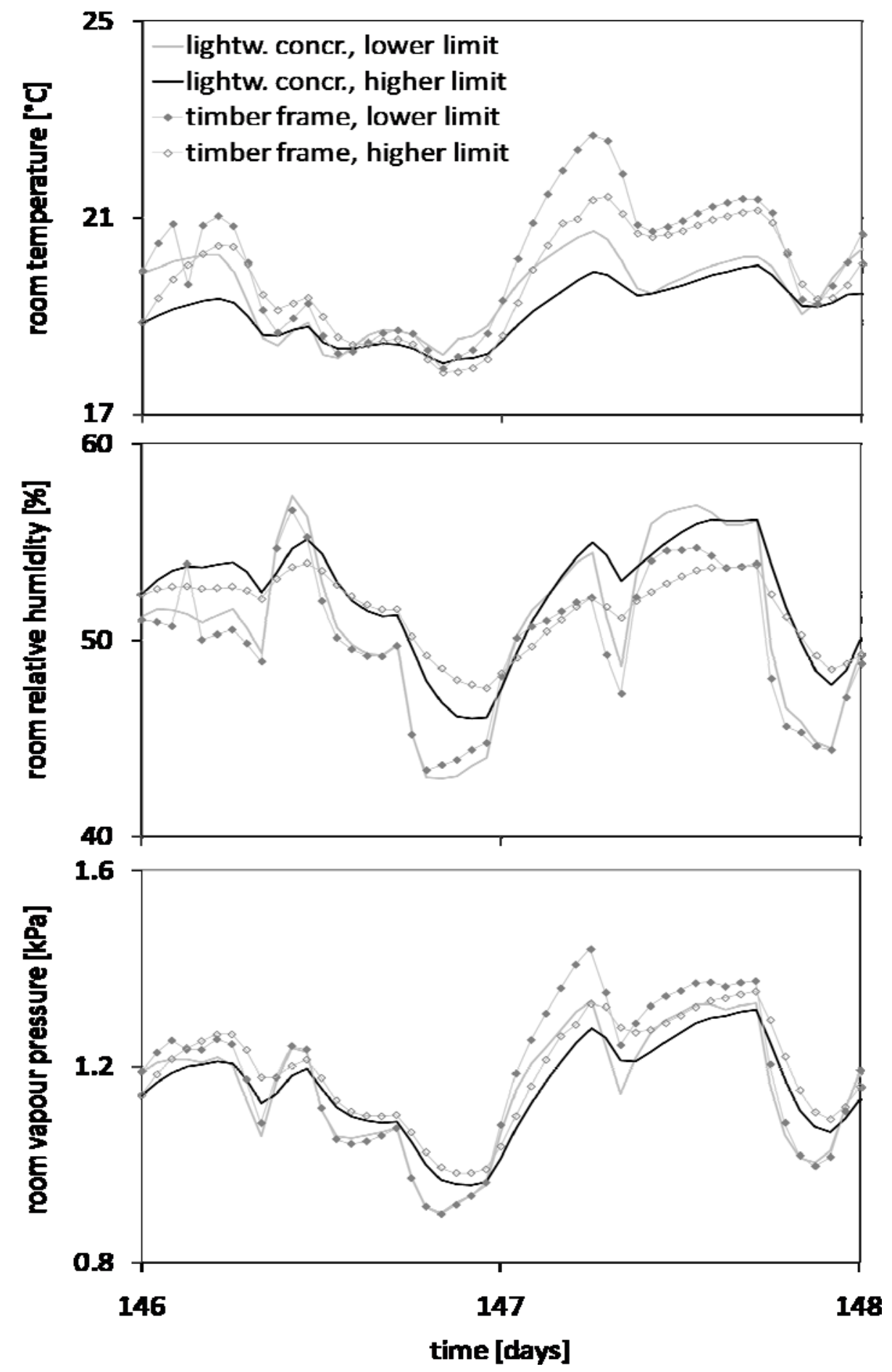


Postprint: Steskens PWMH, Janssen H, Rode C, 2009. Influence of the convective surface transfer coefficients on the Heat, Air, and Moisture (HAM) building performance, Indoor and Built Environment, 18: 245256.

Figure 9
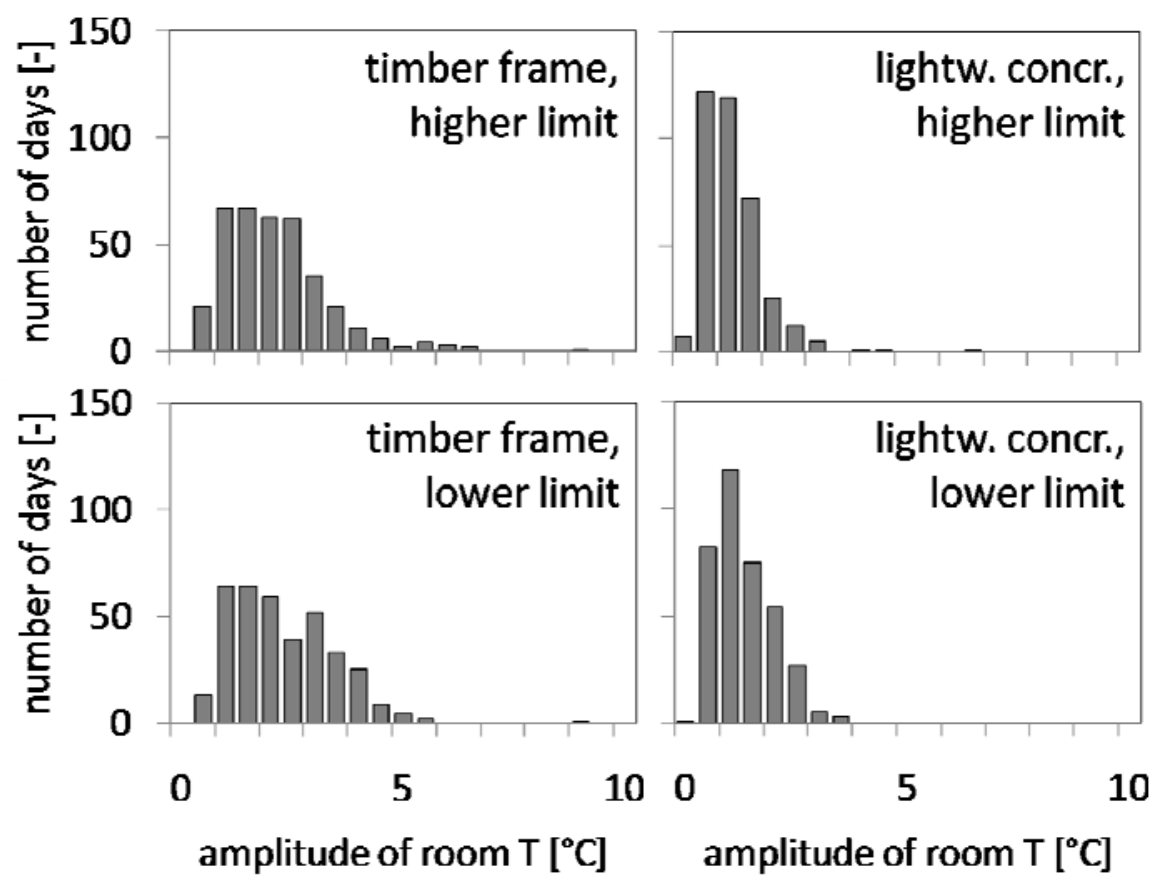

Figure 10

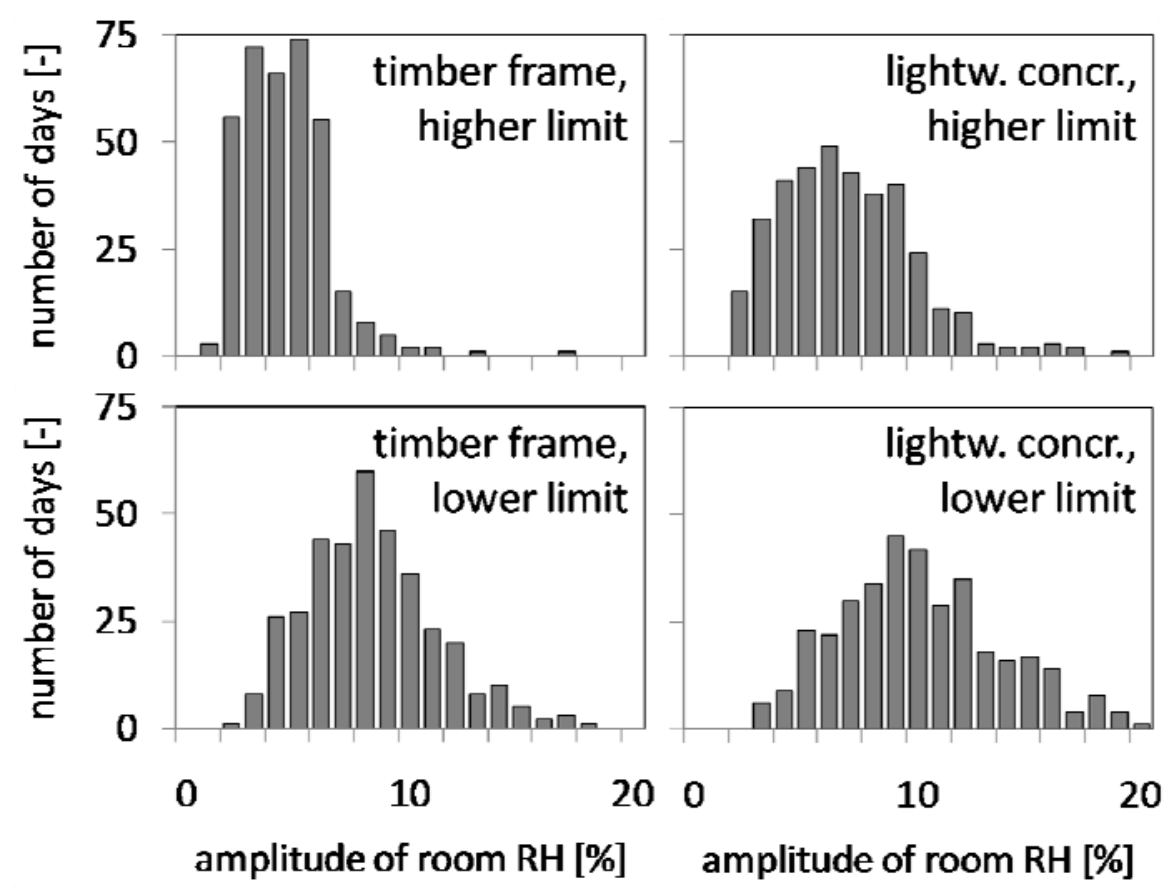


Postprint: Steskens PWMH, Janssen H, Rode C, 2009. Influence of the convective surface transfer coefficients on the Heat, Air, and Moisture (HAM) building performance, Indoor and Built Environment, 18: 245256.

Table 1

\begin{tabular}{|l|l|c|}
\hline Volume $\left[\mathrm{m}^{3}\right]$ & & 129.6 \\
\hline Air change rate $\left[\mathrm{h}^{-1}\right]$ & Constant & 0.75 \\
\hline Internal gains $[\mathrm{W}]$ & Constant & 200.0 \\
\hline Moisture source $\left[\mathrm{g} \mathrm{h}^{-1}\right]$ & $9.00 \mathrm{~h}-17.00 \mathrm{~h}$ & 792 \\
\hline
\end{tabular}

Table 2

\begin{tabular}{|c|c|}
\hline Timber frame wall element & Lightweight concrete wall element \\
\hline $\begin{array}{l}\text { - } 15 \mathrm{~mm} \text { plywood cladding } \\
\text { - } 25 \mathrm{~mm} \text { air cavity } \\
\text { - } 9 \mathrm{~mm} \text { gypsum board wind } \\
\text { barrier } \\
\text { - } 150 \mathrm{~mm} \text { glass mineral wool } \\
\text { - } \quad \text { Vapour barrier } \\
\text { - } 13 \mathrm{~mm} \text { porous wood fibre } \\
\text { board }\end{array}$ & $\begin{array}{l}\text { - } 15 \mathrm{~mm} \text { plywood cladding } \\
\text { - } 25 \mathrm{~mm} \text { vented cavity } \\
\text { - } \text { wind barrier } \\
\text { - } 100 \mathrm{~mm} \text { glass wool } \\
\text { - } 50 \mathrm{~mm} \text { lightweight concrete }\end{array}$ \\
\hline
\end{tabular}

Table 3.

\begin{tabular}{|l|l|c|l|c|}
\hline Cases & Conditions & $\begin{array}{l}\text { Combined surface } \\
\text { transfer coefficient }\end{array}$ & $\begin{array}{l}\text { Convective } \\
\text { surface heat } \\
\text { transfer } \\
\text { coefficient }\end{array}$ & $\begin{array}{l}\text { Convective } \\
\text { surface } \\
\text { moisture } \\
\text { transfer } \\
\text { coefficient }\end{array}$ \\
\hline $\begin{array}{l}\text { 1 Lower } \\
\text { limits }\end{array}$ & $\begin{array}{l}\text { Radiation, no } \\
\text { convection }\end{array}$ & $\alpha=\alpha_{c}+\alpha_{\mathrm{r}}\left[\mathrm{W} \mathrm{m}^{-2} \mathrm{~K}^{-1}\right]$ & $\alpha_{\mathrm{c}}\left[\mathrm{W} \mathrm{m}^{-2} \mathrm{~K}^{-1}\right]$ & $\beta_{\mathrm{c}}\left[10^{-7} \mathrm{~s} \mathrm{~m}^{-1}\right]$ \\
\hline $\begin{array}{l}\text { 2 Upper } \\
\text { limits }\end{array}$ & $\begin{array}{l}\text { Radiation, forced } \\
\text { convection }\end{array}$ & 3 & 1 & 0.1 \\
\hline $\begin{array}{l}3 \text { Lower } \\
\text { limit } \beta_{\mathrm{c}} \text { and } \\
\text { standard } \alpha_{\mathrm{c}}\end{array}$ & $\begin{array}{l}\text { Radiation, natural } \\
\text { convection }\end{array}$ & 8 & 8.5 & 1 \\
\hline $\begin{array}{l}4 \text { Higher } \\
\text { limit } \beta_{\mathrm{c}} \text { and } \\
\text { standard } \alpha_{\mathrm{c}}\end{array}$ & $\begin{array}{l}\text { Radiation, mixed } \\
\text { convection }\end{array}$ & 8 & 3.5 & 0.1 \\
\hline
\end{tabular}


Postprint: Steskens PWMH, Janssen H, Rode C, 2009. Influence of the convective surface transfer coefficients on the Heat, Air, and Moisture (HAM) building performance, Indoor and Built Environment, 18: 245256.

\section{Table 4}

\begin{tabular}{|l|c|c|c|}
\hline & Porous wood fibre & $\begin{array}{c}\text { Lightweight } \\
\text { concrete }\end{array}$ & Concrete \\
\hline $\mathrm{d}[\mathrm{mm}]$ & 13 & 50 & 300 \\
\hline $\mathrm{d}_{\mathrm{p}, \mathrm{M}}[\mathrm{mm}]$ & 1.5 & 3.4 & 1.1 \\
\hline $\mathrm{d}_{\mathrm{p}, \mathrm{H}}[\mathrm{mm}]$ & 56.4 & 9.71 & 15.0 \\
\hline$\lambda\left[\mathrm{W} \mathrm{m}^{-1} \mathrm{~K}^{-1}\right]$ & 0.13 & 0.45 & 2200 \\
\hline$\rho\left[\mathrm{kg} \mathrm{m}^{-3}\right]$ & 450 & 1250 & 840 \\
\hline $\mathrm{c}\left[\mathrm{J} \mathrm{kg}^{-1} \mathrm{~K}^{-1}\right]$ & 2500 & 1050 & $2 \cdot 10^{-12}$ \\
\hline$\delta[\mathrm{s}]$ & $4.5 \cdot 10^{-12}$ & $1.8 \cdot 10^{-11}$ & 0.046 \\
\hline$\xi\left[\mathrm{kg} \mathrm{m}^{-3} \mathrm{~Pa}^{-1}\right]$ & 0.0507 & 0.044 & 0.02 \\
\hline $\mathrm{Bi}_{\mathrm{H}}$ & 0.05 & 0.06 & 2.73 \\
\hline $\mathrm{Bi}_{\mathrm{M}}$ & 1.74 & 0.93 & 1665 \\
\hline $\mathrm{e}_{\mathrm{H}}$ & 382 & 769 & $3.0 \cdot 10^{-7}$ \\
\hline $\mathrm{e}_{\mathrm{M}}$ & $4.8 \cdot 10^{-7}$ & $8.9 \cdot 10^{-7}$ & \\
\hline & & & \\
\hline & & & \\
\hline
\end{tabular}

